\title{
PERAN TOKOH AGAMA DALAM MEMBENTUK PERILAKU KEAGAMAAN PADA MASYARAKAT YANG GEMAR TERHADAP ORGEN TUNGGAL DI KELURAHAN 15 ULU KECAMATAN JAKABARING PALEMBANG
}

\author{
Oleh: \\ Muhammad Kurniawan \\ muhammadkurnawansag@gmail.com \\ Universitas Islam Negeri Raden Fatah Palembang \\ Alfi Julizun Azwar \\ alfijulizunazwar uin@radenfatah.ac.id \\ Universitas Islam Negeri Raden Fatah Palembang \\ Aristophan Firdaus \\ aristophanfirdaus uin@radenfatah.ac.id \\ Universitas Islam Negeri Raden Fatah Palembang
}

\begin{abstract}
The purpose of this study is to explain how the contribution of religious figures in shaping religious behavior in people who are fond of single organism and what are the supporting factors and constraints of religious figures in shaping religious behavior in people who like single organism in Kelurahan 15 Ulu, Jakabaring District, Palembang. The data collection method uses the interview method, documentation observation, the analysis used is a qualitative descriptive approach. The research argues that the role of religious figures in Kelurahan 15 Ulu, Jakabaring Palembang Subdistrict has been good in its implementation, but ineffective in its approach to the community, because religious figures do not really provide counseling or warning advice to people who like single organizations in broadcasting religious knowledge. Sometimes only during the lecture at the wedding reception there is a little question of public discipline in the entertainment of the single organization itself. And it just so happens that most people in Kelurahan 15 Ulu, Jakabaring Subdistrict, Palembang, are less aware of the knowledge of Religion and religious behavior. So that awareness of the knowledge of Religion in Kelurahan 15 Ulu Sub-district of Jakabaring Palembang is lacking in terms of entertainment for the single organization itself.
\end{abstract}

Keywords: religious leader, deviance behavior, remix music

\begin{abstract}
Abstrak
Tujuan dari penelitian ini adalah untuk menjelaskan bagaimana kontribusi tokoh Agama dalam membentuk perilaku keagamaan pada masyarakat yang gemar terhadap orgen tunggal dan apakah faktor-faktor pendukung dan kendala tokoh Agama dalam membentuk perilaku keagamaan pada masyarakat yang gemar terhadap orgen tunggal di Kelurahan 15 Ulu Kecamatan Jakabaring Palembang. Jenis penelitian yang digunakan adalah penelitian kualitatif. Penelitian ini berargumen bahwa peran tokoh Agama yang ada di Kelurahan 15 Ulu Kecamatan Jakabaring Palembang ini sudah baik dalam pelaksanaannya, namun kurang efektif dalam pendekatan kepada masyarakatnya, dikarenakan tokoh Agama tidak begitu memberikan penyuluhan ataupun peringatan nasihat pada masyarakat yang gemar terhadap orgen tunggal dalam menyiarkan ilmu Agama. Terkadang hanya pada saat
\end{abstract}


ceramah di acara resepsi pernikahan disinggung sedikit masalah tata tertib masyarakat dalam hiburan orgen tunggal itu sendiri. Dan kebetulan kebanyakan masyarakat di Kelurahan 15 Ulu Kecamatan Jakabaring Palembang, kurang begitu sadar akan ilmu Agama dan perilaku keagamaan. Sehingga kesadaran akan ilmu Agama di Kelurahan 15 Ulu Kecamatan Jakabaring Palembang ini kurang dalam segi hal hiburan orgen tunggal itu sendiri.

\section{Kata Kunci : tokoh agama, perilaku menyimpang, orgen tunggal}

\section{PENDAHULUAN}

Setiap masyarakat selalu mengalami perubahan yang pada dasarnya, perubahan tersebut, merupakan cerminan budaya dalam suatu masyarakat. Perubahan yang terjadi dalam masyarakat disebut, sebagai perubahan sosial yaitu, gejala umum yang terjadi sepanjang masa pada setiap masyarakat. ${ }^{1}$ Masyarakat merupakan kesatuan hidup manusia yang saling berinteraksi berdasarkan, suatu sistem adat istiadat tertentu. Serta menimbulkan ikatan rasa identitas yang sama, masyarakat sendiri bersifat dinamis selalu bergerak kearah perubahan. Sifat aktif suatu masyarakat dapat berkembang, dan sangat mungkin mengalami perubahan, ${ }^{2}$ perkembangan masyarakat, dalam suatu kumpulan kehidupan bermasyarakat haruslah, memiliki ikatan ketentuan atau kebiasaan yang harus sama-sama ditaati dalam lingkungan. Aturan kehidupan dan ketentuan yang mereka miliki, serta pokok kehidupan sosial dalam masyarakat mempunyai sikap perilaku dan kebiasaan untuk terus menerus menjalankan kesatuan hidup manusia dalam suatu kumpulan individu yang akan terbentuk menjadi bidang sosial tertentu. ${ }^{3}$

Selanjutnya masyarakat, tidak lepas dari sikap perilaku, serta kebiasaan yaitu, keinginan menyukai atau tidak menyukai suatu hal, orang, atau kejadian, ${ }^{4}$ yang menunjukkan perilaku dalam mengutamakan kebutuhan yang berada pada kedudukan yang rendah serta, memiliki berbagai tingkat kebutuhan yang paling tinggi. Suatu keinginan yang pasti untuk mengadakan cara yang baik atau buruk terhadap orang. Selanjutnya, sikap merupakan perihal yang menyangkut, berkenaan berupa kebiasaan untuk bertindak atau merespon dengan cara yang pasti terhadap kesatuan orang, barang dan sebagainya. ${ }^{5}$

Dalam diri manusia, terdapat sikap dan kebiasaan yang bisa membentuk suatu perilaku, baik dan buruk. Tetapi hubungan sikap dengan perilaku tidak sama karena, sikap mempunyai unsur yang berbeda-beda tergantung, pada keadaan yang meliputi seseorang. Unsur yang diperankan akan mempengaruhi nilai secara

\footnotetext{
${ }^{1}$ Kun Maryati, Juju Suryawati, Sosiologi Untuk SMA Dan MA Kelas XII, Jakarta, Erlangga, 2001, hlm. 3

${ }^{2}$ Shinta Afri Tantia, Eksistensi Adat Tunggu Tubing Pada Masyarakat Semende di Desa Pulau Beringin Kecamatan. Pulau Beringin Kabupaten. Oku Selatan, Fakultas Ushuluddin Dan Pemikiran Islam, Uiniversitas Islam Negeri Raden Fatah Palembang. 2018, hlm. 1

${ }^{3}$ Jalaluddin, Psikologi Agama, Jakarta, Raja Grafindo, 2011, hlm. 322

${ }^{4}$ Muhammad Taufiq Amir, Merancang Kusioner Konsep Dan Panduan Untuk Penelitian, Sikap Kepribadian Dan Perilaku, Jakarta, Fajar Interpratama Mandiri, 20115, hlm. 15

${ }^{5}$ Muhammad Faturrohman Dan Sulistyawati, Belajar Dan Pembelajaran Membantu Meningkatkan Mutu Pembejalaran Sesuai Standart Nasional, Yogyakarta, Teras, 2012, hlm. 127
} 
keseluruhan atas suatu gejala. ${ }^{6}$ Sedangkan, perilaku dari sisi psikis dapat diartikan sebagai, suatu kegiatan atau aktivitas susunan yang bersangkutan ${ }^{7}$ kecuali, untuk memperlihatkan perilaku tersebut. Pada umumnya, muncul secara mencolok pada masa kanak-kanak. Oleh karena itu, interaksi sosial yang terjadi pada masyarakat, ${ }^{8}$ memiliki kepribadian yang berbeda juga dalam sikap perilaku dan kebiasaan. ${ }^{9}$ Adapun pengertian kebiasaan, pendapat Witherington ialah, cara bertindak yang diperoleh melalui usaha, secara berulang-ulang yang pada akhirnya menjadi, ketetapan dan bersifat otomatis ${ }^{10}$ dalam sikap perilaku dan kebiasaan seseorang.

Dari sikap perilaku dan kebiasaan, yang dijelaskan di atas, dapat di simpulkan bahwa, sikap perilaku atau kebiasaan merupakan salah satu bentuk dari perbuatan yang dilakukan seseorang dalam melakukan aktivitasnya, pada kehidupan seharihari. Serta sikap yang akan membentuk perilaku seseorang menjadi terbiasa dalam kebiasaan yang dilakukannya di masyarakat. Sikap diyakini mempunyai hubungan yang cukup erat dengan perilaku, keyakinan tersebut kemudian menyebabkan, sikap menjadi sasaran utama dalam usaha yang biasa dilakukan untuk mengubah sikap antara lain komunikasi persuasif. Komunikasi persuasif merupakan penyampaian pesan dari komunikator kepada target melalui media tertentu dengan tujuan untuk mengubah sikap dan perilaku. ${ }^{11}$

Dalam hubungan ini, peran tokoh Agama memiliki peranan yang sangat penting, untuk menanamkan tindakan tentang, sikap perilaku dan kebiasaan masyarakat. ${ }^{12}$ Kemudian, seorang tokoh Agama mempunyai pengaruh yang memadai, ditengah-tengah masyarakat karena, dianggap sebagai tempat dalam menerangkan dan menyelesaikan permasalahan, yang berhubungan dengan ajaran Agama. Maka dari itu, tokoh Agama dalam merencanakan dan mengajak masyarakat untuk mengerjakan, perbuatan baik serta meninggalkan segala perbuatan yang buruk.

Pada masyarakat di Kelurahan 15 Ulu, Kecamatan Jakabaring Palembang, kehadiran musik orgen tunggal di tengah-tengah masyarakat, tidak dapat bertumpu sendiri tanpa berkaitan dengan kebutuhan hidup masyarakat. Sehingga musik orgen tunggal secara umum, dapat beroperasi bermacam-macam dan dapat bertujuan untuk menggembirakan kebutuhan masyarakat baik jasmani maupun rohani. Dapat dilihat, dari gambaran demikian, musik orgen tunggal dalam mengisi kebutuhan rohani dapat digunakan juga dalam acara yang berkaitan, dengan keagamaan. Sedangkan dalam mengisi kebutuhan jasmani merupakan upaya yang dirasakan sebagai hiburan untuk memuaskan waha nafsu.

${ }^{6}$ Anang Firmansyah, Perilaku Konsumen Sikap Dan Pemasaran, Yogyakarta, Deepublish, 2018, hlm.

${ }^{7}$ Eliza Herijulianti, Tati Svasti Indriani, Sri Artini, Pendidikan Kesehatan Gigi, Jakarta, Buku Kedokteran EGC, 2002, hlm. 35

${ }^{8}$ Anantasari, Menyikapi Perilaku Agresif Anak, Yogyakarta, Kanisius Anggota IKAPI, 2006, hlm. 97

${ }^{9}$ Jhon M Ivancevich, Robert Konopaske, Michael T Matteson, Perilakudan Manajemen Organisasi Terjemahan Bahasa Indoneisa, Gelora Aksara Pratama, 2006, hlm. 128

${ }^{10}$ Djaali, Psikologi Pendidikan, Jakarta, Bumu Aksara, 2012, hlm. 128

${ }^{11}$ Agus Abdul Rahman, Psikologi Sosial Integrasi Pengetahuan Wahyu dan Pengetahuan Empirik, Jakarta, Rajawali Pers, 2014, hlm. 142

${ }^{12}$ Nugroho, Zaki Faddad, and Anisa Ramlan. "Respon Tokoh Lintas Agama Tentang AIDS di Palembang." Jurnal Ilmu Agama: Mengkaji Doktrin, Pemikiran, dan Fenomena Agama 21, no. 2 (2020): 196214. 
Dengan keberadaan hiburan orgen tunggal ini, bagi sebagian golongan masyarakat di Kelurahan 15 Ulu Kecamatan Jakabaring Palembang, juga tertarik karena, bisa menyaksikan hiburan secara gratis. Masyarakat sangat mengapresiasi adanya hiburan orgen tunggal tersebut. Bagi masyarakat di Kelurahan 15 Ulu Kecamatan Jakabaring Palembang, terdapat rasa gembira yang sangat luar biasa karena, hiburan orgen tunggal hanya dilaksanakan pada saat ada resepsi pesta perkawinan saja.

Hiburan orgen tunggal ini, sudah dirasakan masyarakat sebagai, keharusan dikarenakan, biasanya masing-masing acara perkawinan yang mengadakan acara selalu mengadakan hiburan orgen tunggal itu sendiri. Kemudian, setiap ada hiburan orgen tunggal biasanya, seorang biduan terlihat cantik dan sexy, serta masih banyak sekali penonton yang ikut berjoget di atas panggung. Hiburan orgen tunggal saat ini, juga beroperasi sebagai hiburan yang mulai digemari oleh masyarakat baik dari para remaja muda maupun tua, untuk mengerjakan hal yang tidak pantas dilakukan seperti, berjoget bersama biduan, mabuk-mabukan, minum obat-obatan terlarang, serta tindak kriminal seperti perkelahian masyarakat sulit dinasihati atau sensitif. ${ }^{13}$ Mengenai hal ini, dikarenakan masyarakat yang sudah salah menafsirkan arti, dari perihal orgen tunggal tersebut.

Berdasarkan hasil, penelitian yang diuraikan di atas, bahwa hiburan orgen tunggal memiliki pengaruh yang cukup besar, pada masyarakat yang gemar terhadap orgen tunggal, di Kelurahan 15 Ulu Kecamatan Jakabaring Palembang. Mengnai hal ini, dilihat dari kenyataannya, tokoh Agama dalam kontribusinya sebagai tauladan, penasihat, pendakwah, dan membujuk masyarakat untuk menuju kebaikan belum terlaksana dengan baik atau adanya suatu penghambat. ${ }^{14}$ Dengan demikian peneliti melihat, sebagian tokoh Agama banyak masih kesulitan dalam melaksanakan tugas sebagai tokoh Agama yang diharapkan dapat mengajak masyarakat dalam membentuk sikap perilaku keagamaan yang baik di dalam sosial kegamaan dimasyarakat. Dan juga peneliti banyak menemui kendala dan hambatan yang di hadapi oleh tokoh Agama. Jika, kondisi-kondisi ini terus menerus terjadi menjadi kebiasaan selanjutnya akan menjadi karakter. Sudah barang tentu, akan menjadi berdampak buruk bagi pribadi, keluarga, dan masyarakat ke depan. ${ }^{15}$

Oleh sebab itu, dalam konteks penelitian ini yang ingin dikaji secara mendalam yakni, bagaimana kontribusi serta apakah faktor-faktor pendukung dan kendala tokoh Agama dalam, membentuk perilaku keagamaan pada masyarakat yang gemar terhadap orgen tunggal di Kelurahan 15 Ulu Kecamatan Jakabaring Palembang ini. Melalui para tokoh Agama paling tidak masih memiliki harapan dan tumpuan untuk memberikan, nilai-nilai Agama dalam kehidupan masyarakat. Oleh karena itu, peran ini mampu disejajarkan untuk kualitas pendidikan, khususnya membentuk perilaku keagamaan yang diharapkan mampu memberikan respon atas

\footnotetext{
${ }^{13}$ Wawancara dengan Bapak Harun Abdullah, Selaku Tokoh Agama di RT 12 Kelurahan 15 Ulu Kecamatan Jakabaring tanggal 5 Maret 2020

${ }^{14}$ Wawancara dengan Bapak Zulkifli, Selaku Masyarakat di RT 12 Kelurahan 15 Ulu Kecamatan Jakabaring tanggal 5 Maret 2020

${ }^{15}$ Abdullah, dan Safarina, Etika Pendidikan, Keluarga, Sekolah Dan Masyarakat, Jakarta, Rajawali Pers, 2015, hlm. 118
} 
kemerosotan nilai-nilai kehidupan secara moral, etika dan spiritual ${ }^{16}$ pada masyarakat yang gemar terhadap orgen tunggal.

Dari paparan di atas, maka penulis tertarik menjadikannya sebagai penelitian mengenai Peran Tokoh Agama Dalam Membentuk Perilaku Keagamaan Pada Masyarakat Yang Gemar Terhadap Orgen Tunggal Di Kelurahan 15 Ulu Kecamatan Jakabaring Palembang.

\section{METODE PENELITIAN}

Jenis penelitian ini adalah peneletian lapangan yang secara langsung orientasinya akan lebih banyak ketempat dimana penelitian dilakukan. Sedangkan lokasi penelitian ini dilakukan di wilayah Kelurahan 15 Ulu Kecamatan Jakabaring Palembang. Untuk mendapatkan data atau memperoleh data yang objektif dalam penelitian ini menggunakan metode Observasi, Wawancara, dan Dokumentasi.

Dari selanjutnya akan dianalisa dengan teknik deskriptif kualitatif, yaitu pengumpulan data untuk menjawab pertanyaan yang berhubungan dengan situasi subjek penelitian saat sekarang ini, dan melaporkan penelitian tersebut sebagaimana adanya.

\section{PEMBAHASAN}

\section{Kontribusi Tokoh Agama Dalam Membentuk Perilaku Keagamaan Masyarakat Penggemar Orgen Tunggal}

Untuk mencapai harapan mulia itu, Blatt dan Kohlberg mengajukan konsep induksi-kognitif, sebagimana telah berhasil diujicobakannya dan berhasil membuat moral masyarakat semakin membaik hari demi hari. Caranya, para masyarakat dibentuk menjadi berbagai kelompok yang menyadari bahwa, jenis ilmu Agama dan umum itu sangat enting buat manusia. Ajaran Agama yang senantiasa mereka kumandangkan adalah, antaran lain. Bekerjalah untuk kepentingan dunia seolaholah engkau akan hidup selama-lamanya dan beramalah untuk mencapai kemenangan akhirat seakan-akan engkau mati besok. ${ }^{17}$

Berdasarkan keterangan di atas, yang sesuai dengan kontribusi seorang Tokoh Agama yang benar, berperan penting dalam membentuk perilaku keagamaan pada masyarakat penggemar orgen tunggal. Karena kontribusi tokoh Agama memang harus berperan penting dalam masyarakat yang dianggap sebagai orang yang mempunyai tingkat yang lebih dalam ilmu Agama, dibandingkan dengan anggota masyarakat yang lain. Oleh karena itu, mereka pada umumnya, memiliki tauladan yang patut dijadikan contoh, dalam membentuk perilaku keagamaan masyarakat di Kelurahan 15 Ulu Kecamatan Jakabaring Palembang, yakni sebagai berikut :

1. Penanaman Nilai-nilai Agama pada Masyarakat

\footnotetext{
${ }^{16}$ Bungaran Antonius Simanjutak, Karakter Batak Masa Lalu, Kini, Dan Masa Depan, Jakarta, Yayasan Obor Indonesia Anggota IKAPI, 2014, hlm. 30

${ }^{17}$ Taufik Abdullah, Agama Dan Perubahan Sosial, Jakarta, Rajawali, 1983, hlm. 168-169
} 
Keluarga merupakan pusat pengembangan religiusitas dan spritualitas, sebab Agama memiliki efek mengintegrasikan keluarga, meningkatkan hubungan antara anggota keluarga. Hal ini merupakan, bahwa remaja yang terlibat beberapa kegiatan keagamaan, bila dibandingkan dengan pemuda yang tidak terlibat, ternyata memiliki hubungan yang erat dengan orangtua. Begitupun remaja, yang orangtuanya sering menghadiri kegiatan keagamaan memiliki hubungan yang lebih baik dengan orangtuanya.

Pada umumnya, keluarga ingin kuat agar anaknya tumbuh dan berkembang menjadi orang yang menjunjung tinggi moral, bisa membedakan mana yang benar dan yang salah, baik dan buruk, pantas dan tidak pantas, sesuai dan tidak sesuai dengan nilai Agama dan sosial. ${ }^{18}$

\section{Mendidik dengan keteladanan}

Konsep dan persepsi masyarakat dipengaruhi unsur, dari luar diri mereka. Hal ini terjadi, sejak remaja masih usia dini, anak-anak melihat, mendengar, mengenal, dan mempelajari hal-hal yang berada di luar diri mereka. Otomatis, perilaku masyarakat dalam kehidupan sehari-sehari adalah perilaku yang diperoleh dari hasil tiruan. Untuk itu, keteladanan tokoh Agama dalam membentuk perilaku keagamaan masyarakat penggemar orgen tunggal, di Kelurahan 15 Ulu Kecamatan Jakabaring Palembang. Perlu sesuatu yang mutlak diperlukan dalam pendidikan keberagamaan masyarakat. Tanpa adanya keteladanan pendidikan apa pun tidak berguna dan nasihat apa pun tidak berpengaruh.

\section{Mendidik dengan pembiasaan}

Pembiasaan merupakan upaya, praktis dalam pembinaan dan pembentukan keberagamaan masyarakat. Nilai keimanan tidak begitu saja hadir dalam jiwa seseorang, tetapi perlu ditanamkan, dipupuk, dan diarahkan agar menjadi kepribadian. Karena iman sifatnya naik turun, tepat sekali pembiasaan mutlak diperlukan agar dapat menangkal pengaruh dari luar yang dapat merusak keimanan. ${ }^{19}$

Menanamkan kebiasaan baik memang tidak mudah mudah dan kadangkadang membutuhkan waktu lama. Tetapi, sesuatu yang menjadi kebiasaan sukar untuk diubah. Untuk itu, hal yang penting adalah seorang tokoh Agama harus menanamkan kebiasaan-kebiasaan baik, tidak mendidik masyarakat untuk berdusta, tidak disiplin, suka berkelahi, dan sebagainya. Tanamkan kebiasaan seperti ikhlas menolong masyarakat yang gemar terhadap orgen tunggal itu sedniri, dalam berpartisipasi dalam kegiatan yang baik-baik, dan sebagainya. ${ }^{20}$

\section{Mengikatnya dengan akidah}

Ini adalah asas yang paling berpengaruh, pada diri mukmin agar selalu merasa diawasi Allah, merasakan keagungan Allah, dan takut kepada-nya, dimana pun dan kapan pun. Ikatan akidah, membuat masyarakat muslim memiliki kekuatan jiwa, dan tidak menjadi budak syahwat atau tawanan hawa nafsu. Sebaliknya,

\footnotetext{
${ }^{18}$ Muhammad Al Mighwar, Psikologi Remaja Petunjuk Bagi Guru Dan Orangtua, Bandung, Pustaka Setia, 2006, hlm. 213

${ }^{19}$ Zuhdiyah, Psikologi Agama Perspektif Islam, Rafah Press UIN Raden Fatah Palembang, Palembang, 2019, hlm. 135-137

${ }^{20}$ Zuhdiyah, Psikologi Agama Perspektif Islam,...hlm. 138
} 
masyarakat akan selalu terdorong melaksanakan ajaran Agama tanpa ragu. Sebagaimana firman Allah dalam Q.S. Al-Maidah : 50

\section{Menjelaskan mudharatnya perbuatan dosa}

Cara ini juga yang dilakukan Al-Quran, untuk memuaskan orang jahiliyah guna meninggalkan tradisi, dan kebiasaan buruk yang penuh dosa. Dalam melakukan pembinaan, dan pembiasaan terhadap masyarakat penggemar orgen tunggal, hendaklah apa yang menjadi larangan harus, ditunjukkan secara jelas hakikat, kejelekan, bahkan keharamnya. Contoh, terhadap konsumsi obat-obatan terlarang, orangtua memberikan gambaran yang rinci tentang bahaya atau mudhorat obat terlarang di mata Allah dan kesehatan.

6. Mengubah lingkungan

Lingkungan yang baik memiliki, pengaruh kuat dalam proses perbaikan individu. Kondisi keluarga yang tidak harmonis atau orangtua yang tidak memberikan kasih sayang utuh, dan berteman dengan kelompok sebaya, atau kurang menghargai nilai-nilai Agama. Maka masyarakat, penggemar orgen tunggal akan bersikap kurang baik atau asusila. Misalnya, minuman keras, membuat keributan, mengkomsumsi obat-obatan terlarang, dan sebagainya.

7. Mendidik dengan nasihat

Nasihat memiliki pengaruh besar untuk membuat masyarakat, mengerti hakikat sesuatu dan memberinya kesadaran tentang, prinsip-prinsip Islam. Terdapat tiga macam nasihat dalam Al-Qur'an yakni sebagai berikut :

a. Nasihat berupa seruan persuasif

Contoh ayat yang menganjurkan nasihat dengan cara seruan persuasif:

Dan (ingatlah) ketika Luqman berkata kepada anaknya, di waktu ia memberi pelajaran kepadanya: "Hai anakku, janganlah kamu mempersekutukan Allah, Sesungguhnya mempersekutukan (Allah) adalah benar-benar kezaliman yang besar".(Q.S. Luqman Ayat : 13)

b. Nasihat berupa kisah yang disertai pelajaran

Islam memerhatikan kecenderungan alami manusia untuk, mendengarkan kisah-kisah sejarah. Di antaranya adalah kisah-kisah para nabi, kisah orang yang durhaka terhadap risalah kenabian serta balasan yang ditimpakan. Al-Qur'an menggunakan kisah untuk segala aspek pendidikan termasuk perilaku keagamaan masyarakat.

\section{c. Mendidik dengan cara memupuk hati nurani}

Pendidikan mental spiritual tidak dapat mencapai sasaran tanpa disertai, pemupukan hati nurani yang merupakan kekuatan dari dalam manusia yang dapat menilai baik buruk suatu perbuatan. Bila hati nurani merasakan senang terhadap perbuatan tersebut, mereka akan merespons dengan baik, bila hati nurani 
merasakan sakit dan menyesal terhadap suatu perbuatan, ia pun merespons dengan buruk. ${ }^{21}$

Menurut Ustadz Muallimin Muslim, lbu Rogaya dan Bapak Hayanudin, menurut mereka, kontibusi peran dan tanggung jawab tokoh Agama, termasuk Majelis Ta'lim, Penyuluh bekerjasama dengan Kementerian Agama dan MUI dan Pemerintah dalam membentuk perilaku keagamaan masyarakat penggemar orgen tunggal salah satunya ialah :

a. Membuat perkumpulan majelis pengajian, supaya untuk memajukan anak-anak muda dan mereka taat dalam mengamalkan ilmu Agama. ${ }^{22}$

b. Masing-masing ada wilayah tertentu yang dibinai, adapun kegiatan perhari tetap mengadakan penyuluhan khususnya, majelis ta'lim. Karena untuk penyuluhan ini ada faktor tertentu, misal kemungkinan umum, rumah sakit lalu RT, itu setiap hari mengadakan majelis ta'lim, terutama khususnya majelis ta'lim yang sudah teregister di Kementerian Agama, jadi kemungkinan mengeluarkan nomor register untuk majelis ta'lim yang di bawahi, dari sana mendukung pekerjaan dari penyuluh. Misal penyuluh disini, dari kegiatan itu dibuat laporan untuk naik tingkat, jadi tanpa adanya majelis ta'lim. Memang banyak kegiatan yang lain, ada juga konseling, lalu ada juga membuat data potensi wilayah. Khusus untuk yang hiburan orgen tunggal itu termasuk dari bimbingan dan penyuluhan, terumata untuk yang intern penyuluhan, ketika ada hiburan tersebut juga bekerjasama dengan penghulu dan juga P2UKD. Peran penyuluh sudah bekerjasama dengan RT, Ketua Masjid, Tokoh Masyarakat yang ada di wilayah tersebut. ${ }^{23}$

c. Setiap ada acara ceramah baik di acara resepsi, atau acara tahlilan, atau acara yang lain-lainya. Selalu disinggung masalah hiburan orgen tunggal itu. Diperbolehkan, akan tetapi terbatas, jangan sampai menggangu dan juga jangan sampai jadi pesta-pesta yang tidak jelas. Kalau hanya ingin bernyanyi tidak menjadi masalah. ${ }^{24}$

d. Mengajak dan memberikan contoh, kepada masyarakat untuk tidak terlalu sering menggemari orgen tunggal, karena sering terjadi keributan dan hal-hal yang tidak kita inginkan. ${ }^{25}$

e. Mengimbangi kalau ada kegiatan hiburan orgen tunggal, supaya tidak mendominasi kegiatan tersebut. Maka diimbangi dengan kegiatankegiatan yang religi atau hiburan-hiburannya disisipkan dengan hiburan yang bersifat religi. ${ }^{26}$

f. Memberikan contoh secara dakwah, dan suatu hal yang baik, jangan melakukan hal yang buruk itu, dan jangan menghadiri hiburan orgen

\footnotetext{
${ }^{21}$ Zuhdiyah, Psikologi Agama Perspektif Islam,...hlm.145

${ }^{22}$ Wawancara dengan Ustadz Muallimin Muslim, Selaku Tokoh Agama di RT 19 Kelurahan. 15 Ulu Kecamatan. Jakabaring Palembang tanggal 8 September 2020.

${ }^{23}$ Wawancara dengan Ibu Rogaya, Selaku Penyuluh Seberang Ulu 1 Cabang di Kelurahan 15 Ulu Kecamatan. Jakabaring Palembang tanggal 21 April 2021

${ }^{24}$ Wawancara dengan Bapak Hayanudin, Selaku Tokoh Masyarakat di RT 47 Kelurahan. 15 Ulu Kecamatan. Jakabaring Palembang tanggal 5 September 2020

${ }^{25}$ Wawancara dengan Ustadzz Darwis, Selaku Tokoh Agama di RT 53 Kelurahan. 15 Ulu Kecamatan. Jakabaring Palembang tanggal 7 September 2020

${ }^{26}$ Wawancara dengan Ustadzz Deni Adi Marsya, Selaku Tokoh Agama di RT 64 Kelurahan 15 Ulu Kecamatan. Jakabaring Palembang tanggal 11 September 2020
} 
tunggal itu. Seandainya kalau mempunyai waktu untuk melakukan itu, jangan sampai melakukan hal yang buruk pada saat hiburan orgen tunggal itu. Jadi masyarakat penggemar orgen tunggal diharapkan, meniru perilaku yang baik seperti itu. Kemudian misalnya, terkadang para ustadz sering diajak untuk bernyanyi, misalnya di acara di orgen tunggal tersebut, jangan sampai ikut dan harus menolak. Karena harus konsisten dan melaksanakan amanah di masyarakat termasuklah pemuka Agama, jangan memberi contoh seperti itu. ${ }^{27}$

Berdasarkan kesimpulan diatas, pentingnya kontribusi tokoh Agama dalam membentuk, perilaku keagamaan masyarakat penggemar orgen tunggal, Sangatlah berpengaruh terhadap perilaku masyarakat. Oleh karena itu, tokoh Agama dianggap cukup berilmu di bidang Agama serta berakhlak mulia, yang mempunyai keahlian baik berkenaan dengan keagamaan sampai wawasan keagamaan yang dijadikan panutan oleh masyarakat sekitarnya. Mereka inilah yang bergelut dalam pengabdian, demi kepentingan di lingkungan masyarakat, karena merekalah, yang mampu menentukan ataupun menempatkan dirinya dilingkungan masyarakat.

\section{Faktor-Faktor Pendukung dan Kendala Tokoh Agama Dalam Membentuk Perilaku Keagamaan masyarakat Penggemar Orgen Tunggal}

Seorang tokoh Agama memiliki tanggung jawab sebagai, pemimpin yang mempengaruhi dan mengarahkan masyarakat menuju fitrah Allah yakni, manusia beragama. Allah swt telah memberikan berbagai kemudahan kepada hamba-Nya yang mau, bersungguh-sungguh untuk melaksanakan aktivitas keagamaan. Akan tetapi, terkadang untuk membentuk perilaku keagamaan masyarakat penggemar orgen tunggal, kepada kebaikan juga tidaklah mudah.

Dalam kaitan ini, peran seorang tokoh Agama dalam masyarakat tentu saja, pasti ada faktor-faktor pendukung dan kendala dalam menjalankan tugas mereka untuk berdakwah. Seiring berjalanya waktu, ada faktor yang mempengaruhi tokoh Agama dalam membentuk perilaku keagamaan masyarakat penggemar orgen tunggal, di Kelurahan 15 Ulu Kecamatan Jakabaring Palembang.

\section{Faktor Pendukung}

Faktor pendukung seorang tokoh Agama, dalam menjalankan perannya membentuk perilaku keagamaan masyarakat penggemar orgen tunggal. Ada beberapa faktor pendukung yang dapat oleh seorang tokoh Agama, dalam membentuk perilaku keagamaan masyarakat penggemar orgen tunggal, untuk mengatasi atau mengendalikan konflik, yaitu:

a. Memberikan kesempatan kepada semua anggota kelompok untuk mengemukakan pendapatnya tentang perilaku pada saat hiburan orgen tunggal.

b. Cara lain yang sering ditempuh untuk mengatasi situasi pada saat hiburan orgen tunggal ialah, dengan meminta satu pihak menempatkan diri pada tokoh Agama, dan memberikan argumentasi kuat mengenasi posisi tersebut. Kemudian posisi peran tokoh Agama itu dibalik, pihak yang tadinya mengajukan argumentasi yang mendukung suatu

\footnotetext{
${ }^{27}$ Wawancara dengan Ustadz Rusydi, Selaku Tokoh Agama di RT 38 Kelurahan. 15 Ulu Kecamatan. Jakabaring Palembang tanggal 8 Septembber 2020
} 
gagasan seolah-olah menentangnya, dan sebaliknya pihak yang tadinya menentang satu gagasan seolah-olah mendukungnya. Setelah itu masing-masing pihak diberi kesempatan untuk melihat posisi orang lain dari sudut pandang pihak lain. ${ }^{28}$

c. Kewenangan pimpinan masyarakat sebagai sumber kekuatan kelompok, Seorang tokoh Agama yang bertugas memimpin suatu masyarakat, untuk mengambil keputusan, atau memecahkan masalah secara efektif, perlu memiliki kemahiran mengunakan kekuasaan atau kewenangan yang melekat pada perannya.

d. Perlu mengadakan saringan atau seleksi terhadap kebudayaan hiburan orgen tunggal yang asing masuk, agar unsur-unsur yang negatif dapat dihindarkan.

e. Agar pendidikan Agama, baik dalam keluarga, sekolah maupun masyarakat secara baik, supaya kehidupan beragama dapat terjamin dan selanjutnya nilai-nilai moral yang baik dapat menjadi bagian pribadi masyarakat kita. Nilai-nilai moral yang pasti, yang terdapat dalam ajaran Agama itu akan membantu setiap masyarakat penggemar orgen tunggal untuk mendapat ketenangan jiwa, sehingga perilaku keagamaan itu ada.

f. Agar diadakan pendidikan khusus untuk masyarakat penggemar orgen tunggal, dalam membentuk perilaku keagamaan di bidang pengajian, supaya mereka dapat membantu dirinya sendiri dalam menghadapi kehidupan sosial, atau untuk menghindari terjadinya kegoncangan jiwa serta terciptanya ketenangan dan kebahagiaan dalam hidupnya seharihari di rumah dan dalam masyarakat.

g. Perlu adanya biro-biro konsultasi, untuk membantu tokoh Agama dalam membentuk perilaku keagamaan masyarakat penggemar orgen tunggal.

h. Dalam kegiatan membentuk perilaku keagamaan itu sebaiknya, pemerintah dengan wewenang yang ada padanya. Serta mengambil tindakan dan langkah-langkah yang tegas, dengan mengikuti sertakan semua lembaga, para ulama dan pimpinan masyarakat. ${ }^{29}$

i. Mendorong gaya hidup sehat serta menghentikan kebiasaan buruk yang akan merusak kesehatan seperti minum-minuman alkohol, obatobat terlarang, serta mendorong untuk patuh, dan berpartisipasi dalam meninggalkan perilaku buruk pada saat hiburan orgen tunggal.

Menurut Bapak Poniar Ghozali, dan Ustadz Halim Sanudin menurut mereka, faktor pendukung tokoh Agama dalam membentuk perilaku keagamaan masyarakat penggemar orgen tunggal salah satunya ialah :

\footnotetext{
${ }^{28}$ Veithzal Rivai, Bachtiar, Boy Rafli Amar, Pemimpinan Dan Kepemimpinan Dalam Organinasi,...hlm. 418

${ }^{29}$ Zakiyah Daradjat, Ilmu Jiwa Agama, Bulan Bintang, Jakarta, 2010, hlm. 155
} 
a. Faktor pendukung sampai saat ini dari Kemenag kementerian Agama sendiri belum ada, yang langsung turun untuk ikut serta dalam penyuluhan masalah hiburan orgen tunggal ke wilayah-wilayah yang rawan daripada permasalahan tersebut. ${ }^{30}$

b. Sebagai ketua peribadatan harus lebih membutuhkan lagi seorang guru untuk sebagai bimbingan serta untuk pencerahannya. Apabila ada seorang makmumanya tidak mau dinasihati, tetap masih seperti itu. Maka cukup berdoa saja dan meminta doa kepada Allah, supaya dibukakan pintu hati masyarakat yang penggemar orgen tunggal tersebut. ${ }^{31}$

Berdasarkan kesimpulan diatas, faktor pendukung tokoh Agama dalam membentuk perilaku keagamaan pada masyarakat penggemar orgen tunggal ialah, ingin mengajak kepada kementerian Agama untuk ikut serta dalam penyuluhan kepada masyarakat penggemar orgen tunggal. Supaya bisa menjelaskan apa yang memang dilarang dalam Agama Islam pada saat hiburan orgen tunggal itu sendiri, supaya tokoh Agama terbantu akan adanya pendukung dari para kementerian Agama serta aparat pemerintah dalam mencegah terjadinya perilaku yang tidak diinginkan dalam hiburan orgen tunggal tersebut.

\section{Faktor Kendala}

Menurut penjelasan data dilapangan bahwasanya, faktor kendala seorang tokoh Agama dalam membentuk perilaku keagamaan masyarakat penggemar orgen tunggal, masih belum berhasil untuk menasihati masyarakat penggemar orgen tunggal itu sendiri. Seorang tokoh Agama tidaklah mungkin tidak pernah mengalami hal-hal yang menjadi kendala dalam menjalankan peranya berikut merupakan hasil dari beberapa wawancara tokoh Agama dalam menjalankan tugas sebagai seorang tokoh dalam masyarakat di Kelurahan 15 Ulu Kecamatan Jakabaring Palembang.

Ustadz Nuryasin dan Ustadz Sowi Sujarwo mereka berpendapat faktor kendala pemuka Agama dalam membentuk perilaku keagamaan masyarakat penggemar orgen tunggal salah satunya ialah :

a. Faktor kendala yang dirasakan ialah, memang harus exstra sabar untuk mendidik orang tua dengan anak anak itu sangatlah berbeda, yang menjadi kendala kami, mudah tersinggung, terus mudah emosi itu kendala yang kami rasakan sekarang ini, terus kemudian kurang kontribusi imbal balik masyarakat yang telah mengajar ke kita itu sangatlah kurang. Itu menjadi salah satu kendala kendala juga, serta juga kurang kesadaran. ${ }^{32}$

b. Kemudian ada tantangan-tantangan yang berupa aturan misalnya aturan negara, yang masih membolehkan itu, tentunya ini tidak bisa dilakukan oleh perseorangan, tetapi harus menggaitkan lembagalembaga pemerintah setempat dan sebagainya. Serta harus berkolaborasi juga dan bersosialiasi, kondisi inilah berbagai macam

\footnotetext{
${ }^{30}$ Wawancara dengan Bapak Poniar Ghozali, Selaku Ketua di Ketua RT 17 Kelurahan. 15 Ulu Kecamatan. Jakabaring Palembang tanggal 8 September 2020

${ }^{31}$ Wawancara dengan Ustadz Halim Sanudin, Selaku Tokoh Agama di RT 15 Kelurahan. 15 Ulu Kecamatan. Jakabaring Palembang tanggal 8 September 2020

${ }^{32}$ Wawancara dengan Ustadz Nuryasin, Selaku Tokoh Agama di RT 64 Kelurahan. 15 Ulu Kecamatan. Jakabaring Palembang tanggal 31 Agustus 2020
} 
profesi saling bahu membahu untuk saling bermusyawarah dalam satu forum. Apalagi khusus di sumsel secara umum di indonesia itu masih diberikan nasihat-nasihat atau ide-ide yang penting untuk melibatkan pemerintah dan sebagainya. Terutama apalagi dalam kebijakan-kebijakan itu maka diberikan masukan-masukan seperti itu. ${ }^{33}$

c. Adanya benturan antara kebijakan-kebijakan yang dilakukan oleh aparat, serta terkadang ada juga kerja sama secara terselubung. Dan memang ada kerja sama yang sistematis, sudah ada nasihat dimasyarakat untuk melarang hiburan orgen tunggal itu, tetapi orang lain mendukung, memang harus dibuat sistematis untuk melaksanakan kegiatan itu walaupun sudah dilarang secara hukum dari kepolisian. Serta tokoh masyarakat, tokoh Agama dapat memberikan mungkin secara persuasif, dengan baik, dengan benar, apa manfaat dan mudhoratny. Untuk itu kembali kepada tuan rumah, siapa yang melakukan dia bertanggung jawab, kalau seperti itu juga tidak mau menerima undangan kalau ada orgen tunggal, ini tergantung dari pemahaman tentang masing-masing tersebut. ${ }^{34}$

Dapat disimpulkan bahwa, mengenai faktor kendala tokoh Agama dalam membentuk perilaku keagamaan masyarakat penggemar orgen tunggal, di Kelurahan 15 Ulu Kecamatan Jakabaring Palembang ini. Sebagian tokoh Agama sudah berupaya untuk mengajak masyarakat penggemar orgen tunggal ini, untuk menjauhi perbuatan yang dilarang oleh syariat Agama Islam serta menasihati apabila ada kejadian yang tidak diinginkan pada saat hiburan orgen tunggal berlangsung.

\section{KESIMPULAN}

Tokoh Agama dalam bermasyarakat mempunyai, tanggung jawab dan kontribusi yang sunguh-sungguh berpengaruh dalam membentuk perilaku keagamaan masyarakat yang gemar terhadap orgen tunggal khususnya, di Kelurahan 15 Ulu Kecamatan Jakabaring Palembang umumnya yaitu : Mengajak masyarakat supaya bisa meninggalkan perbuatan yang dilarang dalam syariat Islam serta menasihati para penggemar orgen tunggal untuk tidak menjadikan hiburan orgen tunggal tersebut sebagai sarana tempat mabuk-mabukan pada saat acara pesta perkawinan. Kedua, mensosialiasikan kepada masyarakat penggemar orgen tunggal untuk ikut kegiatan-kegiatan pengajian Masjid dan ikut serta dalam gotongroyong dalam menciptakan suasana hiburan orgen tunggal itu sendiri sebagai sarana perkumpulan untuk memper-erat tali silahturahmi masyarakat itu sendiri, supaya tidak ada perilaku yang menyimpang pada saat hiburan orgen tunggal tersebut. Ketiga, memberikan penyuluhan kepada lembaga kemasyarakatan Kementerian Agama ataupun Majelis Ulama Indonesia untuk ikut serta, dalam membentuk perilaku keagamaan masyarakat penggemar orgen tunggal itu sendiri, supaya tidak ada hal yang menjadikan suasana resepsi perkawinan itu menjadi unsur-unsur kemungkaran dalam ajaran Agama Islam itu sendiri.

\footnotetext{
${ }^{33}$ Wawancara dengan Ustadz Sowi Sujarwo, Selaku Tokoh Agama di RT 53 Kelurahan. 15 Ulu Kecamatan. Jakabaring Palembang tanggal 11 September 2020

${ }^{34}$ Wawancara dengan Ustadz Ahmad Nazirin, Selaku Tokoh Agama di RT 28 Kelurahan. 15 Ulu Kecamatan. Jakabaring Palembang tanggal 11 September 2020
} 


\section{DAFTAR PUSTAKA}

Abdullah, dan Safarina, Etika Pendidikan, Keluarga, Sekolah Dan Masyarakat, Rajawali Pers, Jakarta, 2015

Abdul, Rahman, Agus, Psikologi Sosial Integrasi Pengetahuan Wahyu dan Pengetahuan Empirik, Rajawali Pers, Jakarta, 2014

Anantasari, Menyikapi Perilaku Agresif Anak, Kanisius Anggota IKAPI, Yogyakarta, 2006

Amir, Taufiq, Muhammad, Merancang Kuesioner, Konsep Dan Panduan Untuk Penelitian Sikap, Kepribadian, Dan Perilaku, Fajar Interratama Mandiri, 2015

Daradjat, Zakiyah, IImu Jiwa Agama, PT Bulan Bintang, Jakarta, 2010

Djaali, Psikologi Pendidikan, Bumi Aksara, Jakarta, 2012

Fathurrohman, Muhammad, Sulistyowati, Belajar Dan Pembelajaran Membantu Meningkatkan Mutu Pembelajaran Sesuai Standart Nasional, Teras, Yogyakarta, 2012

Firmansyah, Anang, Perilaku Konsumen, Sikap Dan Pemasaran, Deepublish, Yogyakarta, 2018

Herijulianti, Eliza, Indriani, Svasti, Tati, Artini, Sri, Pendidikan Kesehatan Gigi, Buku Kedokteran EGC, Jakarta, 2002

Jalaluddin, Psikologi Agama, Raja Grafindo, Jakarta, 2011

Ivancevich, M, Jhon, dan Konopaske, Robert, Matteson, T, Michael, Perilaku Dan Manajemen Organisasi, Terjemahan Bahasa Indonesia, Gelora Aksara Pratama, 2006

Maryati, Kun, dan Suryawati, Juju, Sosiologi Untuk SMA Dan MA Kelas XII, Erlangga, Jakarta, 2001

Nugroho, Zaki Faddad, and Anisa Ramlan. "Respon Tokoh Lintas Agama Tentang AIDS di Palembang." Jurnal IImu Agama: Mengkaji Doktrin, Pemikiran, dan Fenomena Agama 21, no. 2 (2020): 196-214.

Rivai, Veithzal, Bachtiar, Amar, Rafli Boy, Pemimpinan Dan Kepemimpinan Dalam Organinasi, Rajawali Pers, Jakarta, 2014

Simanjutak, Antonius, Bungaran, Karakter Batak Masa Lalu, Kini, Dan Masa Depan, Yayasan Obor Indonesia Anggota IKAPI, Jakarta, 2014

Tantia, Afri, Sinta, Eksistensi Adat Tunggu Tubing Pada Masyarakat Semende Di Desa Pulau Beringin Kecamatan. Pulau Beringin Kabupaten Oku Selatan, Skrispsi, Fakultas Ushuluddin UIN Raden Fatah, Palembang

Wawancara dengan Ustadz Ahmad Nazirin, selaku Tokoh Agama di RT 28 Kelurahan. 15 Ulu Kecamatan. Jakabaring Palembang tanggal 11 September 2020

Wawancara dengan Ustadz Darwis, selaku Tokoh Agama di RT 53 Kelurahan. 15 Ulu Kecamatan. Jakabaring Palembang tanggal 7 September 2020

Wawancara dengan Ustadz Deni Adi Marsya, selaku Tokoh Agama di RT 64 Kelurahan. 15 Ulu Kecamatan. Jakabaring Palembang tanggal 11 September 2020

Wawancara dengan Ustadz Halim Sanudin, selaku Tokoh Agama di RT 15 Kelurahan. 15 Ulu Kecamatan. Jakabaring Palembang tanggal 8 September 2020

Wawancara dengan Ustadz Rusydi, Selaku Tokoh Agama di RT 38 Kelurahan. 15 Ulu Kecamatan. Jakabaring Palembang tanggal 8 Septembber 2020 
Wawancara dengan Ibu Rogaya, Selaku Penyuluh Seberang Ulu 1 Cabang di Kelurahan 15 Ulu Kecamatan Jakabaring Palembang tanggal 21 April 2021

Wawancara dengan Ustadz Nuryasin, selaku Tokoh Agama di RT 64 Kelurahan. 15 Ulu Kecamatan. Jakabaring Palembang tanggal 31 Agustus 2020

Wawancara dengan Bapak Zulkifli, Selaku Masyarakat di RT 12 Kelurahan 15 Ulu Kecamatan Jakabaring tanggal 5 Maret 2020

Wawancara dengan Bapak Harun Abdullah, Selaku Tokoh Agama di RT 12 Kelurahan 15 Ulu Kecamatan Jakabaring tanggal 5 Maret 2020

Wawancara dengan Bapak Poniar Ghozali, selaku Ketua di RT 17 Kelurahan. 15 Ulu Kecamatan. Jakabaring Palembang tanggal 8 September 2020

Wawancara dengan Ustadz Sowi Sujarwo, selaku Tokoh Agama di RT 53 Kelurahan. 15 Ulu Kecamatan. Jakabaring Palembang tanggal 11 September 2020

Zuhdiyah, Psikologi Agama Perspektif Islam, Rafah Press UIN Raden Fatah, Palembang, 2019 